\title{
Negosiasi Pemuda dalam Fleksibilitas Pasar Kerja: Studi Netnografi terhadap Mikro-Selebriti di
}

\section{Daerah Istimewa Yogyakarta}

\section{Arif Budi Darmawan, Faishal Abdul Azis, Mei Nurul Aini}

Pusat Studi Asia Tenggara UGM dan Departemen Sosiologi Fisipol UGM

arif.budi@mail.ugm.ac.id | faishal.abdula65@gmail.com | mei.nurul.a@mail.ugm.ac.id

\begin{abstract}
Today the labor market flexibility to be a trend among young people. This emergence of flexibility becomes an ambivalence. On the one hand, it is a form of adaptation with increasingly mobile work. However, according to Guy Standing flexibility actually produces new dangerous class. The vulnerability arises in the form of no guarantee of protection for workers and the security of the labor market. Through netnographic studies the author seeks to examine the employment choices of youth as micro-celebrities, the benefits gained, obstacles faced and negotiations carried out to answer the uncertainty that leads to his work. The researcher observed through the internet and conducted in-depth interviews. The selection of research informants was purposively conducted, namely, micro-Sebritic workers living in the Special Region of Yogyakarta in ages 16-30 years. From the results of the study found that: First, working as a micro-celebrity is the need for leisure. For young people working as micro-celebrities is a hobby as well as a profession. Second, many micro-celebrities are faced with dilemmas and uncertainty situations, both coming from themselves and parents. Finally, negotiations are carried out by youth to deal with uncertainty over their work and the dilemma they face.
\end{abstract}

\section{KEYWORDS Labor Market Flexibility | Micro-celebrity | Generation Perspective}

\section{PENDAHULUAN}

'Disrupsi menggantikan 'pasar lama', industri dan teknologi menghasilkan suatu kebaruan yang lebih efisien dan menyeluruh. Ia bersifat destruktif dan kreatif"-Clayton Christensen (dalam Kasali 2017).

Petikan dari Clayton Christen di atas menggambar sebuah ambivalensi teknologi. Ia hadir layaknya dua sisi mata uang yang tidak dapat dipisahkan. Di satu sisi, hadirnya inovasi teknologi mampu mempermudah pekerjaan manusia. Akan tetapi, di sisi lain teknologi turut serta menggusur struktur lama yang seolah terlihat mapan (Kasali 2017). Revolusi industri 4.0 dengan mengusung inovasi teknologi mengubah seluruh aspek kehidupan manusia (Schawab 2016). Tidak hanya dalam tataran individu, perkembangan teknologi yang amat pesat turut memengaruhi kondisi ekonomi, bisnis, dan pemerintahan baik dalam lanskap nasional maupun global (Schawab 2016).

Schawab (2016) menuturkan kata "revolusi” pada revolusi industri menunjukkan perubahan yang amat mendasar, terjadi secara cepat, dan berdampak secara luas. Sejarah telah membuktikan dalam setiap revolusi industri senantiasa diikuti dengan perubahan sistem pasar. Dimulai sejak revolusi industri pertama pada tahun 1760-1840. Hadirnya mesin uap turut memengaruhi perubahan radikal masyarakat Eropa dan seluruh dunia (Drath and Horch 2014) 
Revolusi industri pertama mengubah struktur pekerjaan masyarakat dari sektor agrikultur menuju sektor industri (Drath and Horch 2014).

Baru pada akhir abad ke-19 dimulailah era revolusi industri kedua. Pada era ini terjadi perkembangan industri produk massal sebagai akibat ditemukannya teknologi listrik (Schawab 2016). Industri massal pada revolusi industri kedua ini merujuk pada industri mobil. Berbeda dengan era sebelumnya, mobil hanya dapat dijangkau oleh beberapa kalangan. Fenomena ini oleh Antonio Gramsci disebut dengan era fordisme -merujuk pada Henry Ford sebagai inisiator industri massal mobil pada tahun 1890 . Fordisme menunjukkan era baru masyarakat kapitalisme di mana produksi industri semakin meningkat, produksi dilakukan secara massal dan barang mampu dijangkau oleh banyak kalangan (Freyssenet and Jetin 2009). Masih dalam abad yang sama, tahun 1960, dimulailah babak baru revolusi industri ketiga dengan ditemukannya komputer dan internet (Schawab 2016).

Berbeda dengan tiga revolusi sebelumnya, dalam revolusi industri 4.0 teknologi semakin berkembang pesat. Disrupsi teknologi, istilah tersebut lebih khusus digunakan untuk menggambarkan fenomena munculnya inovasi teknologi besar-besaran yang berdampak pada perubahan struktur pasar (Kasali 2017). Manusia dewasa ini tidak hanya bersaing dengan manusia lainnya, tetapi bersaing dengan teknologi. Inovasi teknologi, yang salah satunya hadir dalam rupa kecerdasan buatan sengaja diciptakan untuk mempermudah pekerjaan manusia (Ustundag and Cevikcan 2018). Alih-alih membantu, teknologi justru semakin menggusur pekerjaan manusia dan menciptakan pekerjaan baru yang berbeda dari era sebelumnya (Kasali 2017).

Sherly Tuckle (2018) dalam bukunya, Alone Together: Why We Expect More from Technology and Less from Each Other, menjelaskan bagaimana teknologi mampu menggusur pekerjaan manusia. Di Jepang, robot dengan basis kecerdasan buatan diciptakan sebagai tenaga kerja rumah tangga. Hal ini dilakukan sebagai antisipasi terhadap ledakan usia tua dalam struktur demografi masyarakat Jepang. Menciptakan robot dianggap lebih efisien ketimbang harus mendatangkan tenaga kerja asing. Tuckle menambahkan pula bahwa lebih dari satu dekade penemuan robotika di Amerika menjadikan Jepang sebagai contoh ideal bagi masa depan. Robot dianggap lebih sabar, lebih peduli dan lebih baik dalam menghadapi orang tua. Makna peduli pada 'mesin yang peduli' (caring machine) lebih pada tindakan merawat dan menjaga bukan dalam hal perasaan (Turkle 2018).

Sedangkan pada struktur pasar terjadi perubahan dari era fordisme menuju Post-fordisme (White 2014). Salah satu ciri era Post-fordisme adalah 'fleksibilitas pasar kerja' (labor market flexibility). Hal ini berbeda dengan pasar kerja pada era sebelumnya, pasar kerja lebih hierarkis, birokratis, dan absolut (Vallas 1999). Industri 4.0 tidak hanya membawa kesempatan baru melalui sistem 'ekonomi berbagi' (sharing economy) (Lindawati 2019), tetapi ia juga membawa jebakan-jebakan baru serta menghadirkan masyarakat dengan risiko tinggi (Giddens 2016).

Guy Standing (2011) menjelaskan bahwa jebakan teknologi itu salah satunya muncul berupa meningkatnya kelas 'pekerja prekariat' (the precarious work). Istilah prekariat berasal dari dua kata yakni, precarious (rentan) dan proletariat (pekerja). Istilah ini muncul akibat sistem ekonomi Neoliberal dimana fleksibilitas pasar kerja harus ditingkatkan untuk memindahkan risiko pekerjaan pada pekerja dan keluarganya. Oleh karena ketidakamanan jaminan pekerjaan, pekerja prekariat dianggap sebagai 'kelas baru yang rentan' (a new dangerous class) (Standing 2011).

Standing menambahkan bahwa anak muda, utamanya di negara-negara berkembang, menjadi salah satu pemasok terbesar dalam kelas pekerja prekariat. Pasar kerja baru membuat anak muda cenderung beralih pada struktur 
pekerjaan yang lebih fleksibel dan tidak terikat. Hadirnya fleksibilitas kerja merupakan efek dari tren ekonomi global dan reproduksi ekonomi kapitalis (Wyn et al. 2014). Implikasi dari fleksibilitas pasar kerja ini adalah pemuda yang mengalami kerentanan atas eksploitasi. Wyn dan White (1997) menambahkan eksploitasi tersebut hadir berupa hilangnya pekerja penuh waktu, rendahnya jaminan keamanan pekerjaan, dan eksploitasi tersembunyi berupa tidak adanya aturan yang jelas mengenai waktu jam kerja.

Majalah Fortune dalam sampulnya pada tahun 1994 memprediksikan fenomena fleksibilitas pasar kerja ini sebagai "The End of The Job" (Florida 2012). Pada fase ini anak muda akan bertanya terhadap generasi sebelum perihal bagaimana rasanya dipekerjakan? Daniel Pienk (Florida 2012), memberikan istilah "Free Agent Nation”, untuk mengidentifikasikan kelas pekerja baru yang berbeda dari kelas pekerja lama yang lebih terstuktur dan birokratis menuju era pekerja lepas.

Konektivitas antara revolusi industri 4.0 dan perubahan budaya kerja menghasilkan kelas 'pekerja digital' (digital labor). Mereka - pekerja digital- bekerja melalui platform teknologi internet yang menghasilkan fitur kolaborasi dan interaksi. Pekerja digital bekerja melalui lini media baru seperti Youtube, Twitter, dan Instagram. Bagi sebagian aktivis konektivitas pemuda pada internet dan media sosial merupakan masa depan bagi prekariat (Standing 2011). Media sosial bukan sekadar media, ia adalah sebuah media kontestasi dan sebuah praktik produksi baru (Fisher and Fuchs 2014). Pekerja digital ini kerap disebut sebagai mikro-selebriti.

Dalam buku Cam Girls: Celebrity and Community in the Age of Social Networks, Theresia Sneft (2008) mendefinisikan mikro selebriti sebegai berikut:

Micro Celebrity is a new syle of online performance in which people employ webcams, video, audio, blogs, and social networking sites to 'am up' their popularity among readers, viewers, and whose to whom they are linked online.
Definisi yang diberikan oleh Senft ini senada dengan apa yang disampaikan oleh Marwick (2015) terkait mikro-selebriti. Marwick secara khusus mendefinisikan mikro-selebriti sebagai pekerja digital yang memanfaatkan platform Youtube, Instagram, dan beberapa lini media baru lainnya.

Mikro-seleberiti bisa juga disebut dengan internet selebiriti, merujuk pada selebriti yang lahir dari jejaring internet. Hadirnya internet turut memberikan ruang bagi indvidu untuk memperoleh audiens dalam jumlah banyak. Melalui media sosial setiap individu dapat menjadi selebriti dan bersaing untuk mendapatkan pengakuan dan penggemar (Marwick and Boyd 2011). Untuk menarik perhatian audiens mikroselebriti membagikan konten video, blog dan foto pada jejaring media sosialnya baik berupa tulisan blog, video blog (vlog) ataupun berupa gambar (Marwick and Boyd 2011; Senft 2008). Mikro-selebriti tidak akan menjadi populer jika tidak memanfaatkan media sosial. Akun media sosial dikelola sedemikian rupa dengan tujuan untuk menarik perhatian warga net.

Pilihan profesi sebagai mikro-selebriti tentu mengalami pertentangan dengan orang tua yang notabene lahir dari generasi yang berbeda. Dalam studi kepemudaan khususnya dalam perspektif generasi melihat pemuda sesuai dengan konteks sosialnya (Naafs and White 2012b). Di era modern ini anak muda mengalami pengalaman hidup yang sangat berbeda pada generasi sebelumnya. Generasi muda saat ini berada di era Post-fordisme, di mana fleksibilitas pasar kerja terjadi. Sebagai konsekuensi, pemuda harus beradaptasi dan bernegosiasi dengan pelbagai kerentanan serta dilema yang dihadapinya.

\section{KAJIAN LITERATUR}

Selama ini kajian terhadap mikro-selebriti hanya terbatas pada kajian terkait citra yang ditampilkan di media sosial. Salah satunya kajian dengan judul "Fenomena Mikro-selebriti di Instagram: Analisis Semiotika Presentasi Diri Karin Novilda”. Dalam kajian tersebut dipapar 
kan bagaimana mikro-selebriti melakukan presentasi diri melalui akun media sosial. Presentasi diri ini merupakan bentuk interaksi mikro-selebriti dengan khalayak publik maya (Simangunsong 2018). Marwick -salah satu pegiat kajian mikro-selebriti- dalam beberapa artikelnya juga memaparkan bagaimana self-branding yang dilakukan oleh mikro selebriti baik berupa kekayaan yang kerap ditampilkan melalui sosial media (Marwick 2015) merupakan akibat dari globalisasi dan meluasnya consumer capitalism (Khamis, Ang, and Welling 2017).

Sementara itu dalam hal kerentanan pekerja, kajian hanya terbatas pada kerentanan yang dialami mikro-selebriti sebagai pekerja immaterial (Pratitis 2017). Dalam studi tersebut dijelaskan bahwa komersialisasi vlog (video blog) memiliki posisi yang rentan dalam 'proses pembentukan kelas pekerja' (class in the making). Kerentanan tersebut antara lain berupa rendahnya upah, tidak adanya jaminan perlindungan pada kecelakaan kerja, dan jaminan keamanan pendapatan (Pratitis, 2017).

Secara spesifik artikel ini berfokus pada kajian kepemudaan yakni bagaimana negosiasi terhadap kerentanan yang dialami oleh pemuda yang bekerja sebagai mikro-selebriti. Pemuda dan kerentanan merupakan merupakan dua hal yang tidak dapat dipisahkan. Utamanya dalam konteks Indonesia yang dimulai sejak mencuatnya hagemoni rezim neo-liberal (Sutopo and Meiji 2014). Sebagai konsekuensi tersebut pemuda harus menghadapi tantangan berupa hambatan struktural yang semakin besar. Hambatan tersebut hadir berupa sulitnya memperoleh pekerjaan sesuai aspirasi pemuda dan 'ketidakamaan pekerjaan' (job insecurity) (Sutopo and Meiji 2014).

Dalam menghadapi ketidakpastian dunia kerja pemuda melakukan serangkaian negosiasi dalam menghadapi zigzag journey menuju dunia kerja yang mereka cita-citakan. Pemuda juga melakukan strategi jangka panjang berupa mengumpulkan kapital yang nantinya akan dikonversi di masa depan (Sutopo 2013). Nilan,
Julian, dan Germov (2007) (dalam Sutopo 2013) menjelaskan zigzag journey sebagai sebuah fase yang dialami pemuda pasca menghadapi dunia pendidikan dan berjuang dalam menghadapi dunia kerja. Dalam proses zigzag journey ini pemuda harus menjalani pekerjaan sementara yang tidak mereka senangi. Adanya harapan dan ambisi yang kuat membuat pemuda tetap tekun dan uletdalam menghadapi fase zigzag journey ini (Sutopo 2013).

\section{METODE PENELITIAN}

Tulisan ini menggunakan pendekatan kualitatif untuk mengeksplorasi dan memahami makna atas individu atau kelompok sosial (Cresswell 2015). Eksplorasi berfokus pada anak muda yang bekerja dengan memanfaatkan jaringan maya. Dunia kita saat ini semakin mengarah pada ranah digital, jutaan orang berinteraksi melalui jejaring maya dan budaya siber (Kozinets 2010). Oleh karena itu, studi netnografi dirasa sesuai untuk memahami fenomena tersebut.

Netnografi merupakan sebuah metode untuk mengungkapkan dan menganalisis presentasi diri yang digunakan oleh masyarakat untuk mengontruksi 'diri digital'-nya (self digital) serta untuk memahami suatu komunitas dan budaya yang termanifestasikan dalam interaksi daring (Kozinets 2010). Metode ini dirancang untuk pendekatan kualitatif yang memadukan antara internet dan etnografi. Berbeda dengan etnografi, basis observasi pada studi netnografi adalah dalam ranah daring (Flick 2014).

Pemilihan informan penelitian dilakukan secara purposif. Dalam teknik ini pemilihan informan dilakukan seturut dengan kebutuhan peneliti (Cresswell 2015). Sesuai dengan Undang-Undang No. 40 tahun 2009, maka informan penelitian ini adalah pemuda berusia 1630 tahun yang bekerja sebagai mikro-selebriti dan berdomisili di Daerah Istimewa Yogyakarta. Terdapat empat informan dalam penelitian ini, di antaranya; HF (Youtuber, 22 tahun), AF (Youtuber, 22 tahun), DGS (Youtuber, 20 tahun), dan GHP (Selebgram, 23 tahun). 
Dalam studi netnografi ini teknik pengumpulan data dilakukan dengan dua cara, yakni observasi daring dan wawancara mendalam. Observasi daring dilakukan dengan mengamati kanal media sosial keempat informan. Observasi dilakukan pada tanggal 15 Februari 2019 15 April 2019. Observasi daring dilakukan untuk mengetahui aktivitas informan dalam jejaring maya. Dalam studi netnografi, wawancara mendalam dapat dilakukan untuk mendapatkan pemahaman yang lebih dalam atas observasi daring. Wawancara dapat dilakukan secara langsung ataupun secara daring melalui surel (Kozinets 2010).

\section{KERANGKA TEORI}

\section{A. Pekerja Immaterial}

Dalam bukunya, Multitude: War and Democracy in the Age of Empire, Michele Hardt dan Antonio Negri (2005) menyatakan bahwa kelas pekerja senantiasa berubah. Jika di awal abad ke 18 dan 19 dunia dihegemoni oleh pekerja industri dan sebagian kecil dalam produksi agrikultur. Maka dimulai pada abad ke-20 mulai muncul kelas pekerja immaterial (immaterial labor), yakni pekerja yang memproduksi suatu hal yang sifatnya immaterial seperti pengetahuaan, informasi, komunikasi, dan respon emosional (Hardt and Negri 2005).

Secara konvensional pekerjaan jenis ini hadir dalam bentuk pelayanan jasa (service work), kerja intelektual (intelectual labor), dan kerja kognitif (cognitive labor). Terdapat dua jenis pekerja immaterial, pertama, mengacu pada intelektual dan linguistik. Produk yang dihasilkan berupa simbol dan gambar. Jenis kedua, adalah pekerja afektif (affective labor), mereka memberikan manipulasi pengaruh perasaan nyaman, kepuasaan, dan kegembiraan (Hardt and Negri 2005). Jika merunut pada penjelasan Hardt dan Negri maka mikro-selebriti dapat dikategorikan ke dalam pekerja immaterial. Mikro-selebriti memproduksi informasi dan pengetahuan melalui konten yang dibuatnya serta memberikan manipulasi perasaan pada penontonnya.

"There is one tendency, for example, in various forms of immaterial labor to blur the distinction between work time and non work time, extending the working day indefinitely to fill all of life, and another tendency for immaterial labor to function without stable long-term contracts and thus to adopt the precarious position of becoming flexible (to accomplish several tasks) and mobile (to move continually among locations)." (Hard dan Negri 2005: 87).

Sebagaimana bunyi kutipan di atas, Hard dan Negri menyatakan bahwa sebagai pekerja immaterial tidak lepas dari kerentanan. Pekerja immaterial menghadapi kerentanan berupa ketidakjelasan waktu kerja. Selain itu kerentanan hadir berupa minimnya proteksi terhadap pekerja immaterial dalam menghadapi risikorisiko yang akan dihadapinya. Hard dan Negri (2005) menegaskan posisi fleksibilitas pekerja immaterial sangatlah rentan. Fleksibilitas membuat para pekerja untuk menyelsaikan beberapa tugas dan untuk bekerja terus menerus.

\section{B. Perspektif Generasi}

Terdapat beragam perspektif yang digunakan dalam melihat isu kepemudaan. Naafs dan White (2012) dalam artikelnya memberikan tinjauan reflektif atas kajian-kajian isu kepemudaan di Indonesia. Terdapat tiga perspektif sebagai hasil dari pengorganisasian kajian-kajian terdahulu mengenai isu kepemudaan tersebut. Ketiga perspektif tersebut antara lain; pemuda dalam perspektif transisi, pemuda dalam perspektif generasi, dan pemuda dalam perspektif budaya (Naafs and White 2012b). Secara khusus tulisan ini menggunakan perspektif generasi untuk mengeksplorasi pilihan pemuda yang berkarier menjadi mikro-selebriti.

Perspektif generasi dinilai dapat menjelaskan kondisi pemuda Indonesia kontemporer. Penjelasan tersebut berupa perubahan sosial, ekonomi, budaya, dan politik pasca-reformasi terjadi serta bagaimana pemaknaan subjektif pemuda dalam menghadapi perubahan tersebut (Sutopo 2014). Salah satu isu yang dihadapi 
pemuda Indonesia -sebagaimana yang telah penulis paparkan di bagian pendahuluan- adalah kehadiran revolusi industri 4.0.

Pengembangan analisis pemuda dalam perspektif generasi berasal dari pemikiran Karl Mannheim dalam esainya berjudul "The Problem of Generation” (Naafs and White, 2012). Dalam esainya tersebut Mannheim berpendapat bahwa akan selalu ada pertentangan antar-generasi yang disebabkan oleh lokasi sosial dan konteks sosio-historis yang berbeda. Mannheim menambahkan baik lokasi sosial maupun konteks sosio-historis keduanya membentuk suatu nilai, kepercayaan, dan pandangan hidup suatu generasi. Kelompok generasi yang berbeda serta perbedaan konteks sosio-historis menimbulkan konflik antar-generasi (Sutopo 2014).

Dalam perspektif generasi, pemuda tidak hanya dimaknai menurut rentang usia seseorang dalam struktur demografi (Naafs and White 2012b). Hal tersebut merupakan perspektif deterministik yang mengkategorikan pemuda dalam rentang usia tertentu (White and Wyn 1998). PBB misalkan mendefinisikan pemuda dalam rentang usia 15-24 tahun sementara di Indonesia, menurut UU No 40 tahun 2009, mendefinisikan pemuda dalam rentang usia 16-30 tahun (Naafs and White 2012b). Akan tetapi lebih dari itu generasi dipahami sebagai suatu yang relasional dengan konteks sosialnya. Pada pemaknaan ini generasi muda menjadi bagian yang membedakan diri mereka dengan kategori sosial lainnya (Sutopo 2014).

Untuk memahami perspektif generasi perlu melihat konteks yang relasional dengan kondisi sosial pemuda (Sutopo 2014). Dalam konteks Indonesia makna "generasi" lebih relevan sebagai kategori sosial yang memiliki kesamaan. Sebagai contoh di Indonesia muncul 'angkatan' pemuda dari masing-masing generasi seperti, angkatan 45, angkatan 65, Angkatan 98, dan seterusnya (Naafs and White 2012a). Angkatan tersebut ingin menunjukkan konteks sosial pada masa itu (Sutopo 2014). Ben Anderson dalam pembahasannya mengenai Angkatan Mudamerujuk pada generasi muda awal Indonesia tahun 1945- menjelaskan konteks sosial pemuda pada zamannya. Pemuda di Jawa pada saat itu lahir dalam konteks perjuangan terhadap penjajan Jepang. Sehingga Angkatan Muda harus berjuang dalam garis depan politik nasional (Anderson 1972).

\section{TEMUAN DAN ANALISIS}

Dalam bagian ini penulis memaparkan temuan dan hasil penelitian. Terdapat dua pokok bahasan: pertama, kegemaran (passion) yang sekaligus dapat menghasilkan pundi rupiah, dan menjadi profesi menjadi ketertarikan pemuda untuk terjun ke dalam dunia mikro-selebriti. Kedua, negosiasi yang dilakukan pemuda untuk tetap melanjutkan kariernya sebagai seorang mikro-selebriti.

A. Hobi, Menghasilkan Pundi, dan Menjadi Profesi: Narasi tehadap Mikro-Selebriti

"Dari sudut pandang individu, saya hanya mau men-
yalurkan hobi saya dalam hal videografi. Meny-
iapkan untuk masa depan karena ke depan saya juga
ingin bekerja dalam bidang videografi". -HF ( 22 ta-
hun, Youtuber)

Dari penuturan informan menyebutkan bahwa membuat kanal Youtube adalah salah satu cara untuk menyalurkan hobi di bidang videografi. Hobi, pundi, dan profesi menjadi tiga hal yang saling bertautan dalam menentukan pilihan karier pemuda sebagai mikro-selebriti. HF (22 tahun), pemuda asal Jakarta ini memulai kariernya sebagai Youtuber sejak 10 Oktober 2018. Ia bersama dua orang temannya, AF (22 tahun) dan CD (22 tahun), membuat kanal Youtube bernama "Departemen Gaje". Kanal tersebut berisikan konten hiburan dan literasi.

Dari petikan HF di atas dapat dipahami bahwa menjadi seorang Youtuber merupakan fase zigzag journey. Menilik pada studi sebelumnya terkait strategi pemuda dalam dunia kerja (Sutopo 2013), yang mamaparkan bahwa zig-zag 
journey merupakan strategi jangka panjang untuk mengakumulasikan modal-modal yang akan dikonversi di masa depan. Dalam hal ini HF tengah mengakumulasikan modal berupa keterampilan dalam bidang videografi.

Salah satu yang menarik dari kanal ini adalah tulisan pada kotak deskripsi pada kanal “Departemen Gaje”. Pada kotak tersebut dituliskan bahwa kanal tersebut dibuat lantaran jenuh dengan tugas akhir (skripsi). Kelak ketika lulus mereka berharap tidak ingin menjadi pekerja kantoran yang mereka anggap membosankan. Sebagai youtuber mereka dapat bebas mengeksplorasi dan berkreasi terkait konten yang mereka buat. Tidak ada aturan jam kerja tertentu yang membuat mereka bebas menentukan waktu kerja. Dalam sebulan mereka menargetkan untuk mengunggah delapan video, sehingga setiap minggu minimal harus mengunggah 2 video, sebagaimana dijelaskan:

“Minimal kami sebulan upload 8 kali, karena kami menargetkan setiap Minggu upload dua kali. Ide banyak karena kami bertiga. Cuma susahnya terkadang mengelaborasi ide tiga orang." -HF (22 tahun, Youtuber)

Menurut HF, dalam membuat konten kreatif harus memiliki ciri khas dari konten yang dibuat oleh Youtuber lainnya. Salah satu ciri khas yang dibawa dalam kanal "Departemen Gaje" yakni kekhasan pembawa acara dan meme yang selalu diselipkan dalam setiap video. Terkait proses pembuatan konten mencakup dua hal yakni pra dan pasca pengambilan video. Tahapan pra pengambilan mencakup diskusi topik, kebaruan dari topik yang pernah ditayangkan, penentuan narasumber, dan penentuan teknik pengambilan gambar. Sedangkan tahap kedua atau pasca-pengambilan yakni proses pengeditan.

HF menuturkan bahwa penghasilan sebagai youtuber didapat dari dua hal. Pertama, melalui Google AdSense yaki berupa iklan berbayar yang disisipkan oleh pihak Google. Kedua, penghasilan didapat melalui endorsement, yakni berupa video iklan berdasarkan pesanan oleh pihak tertentu. Untuk mendapatkan penghasilan dari Google AdSense minimal seorang youtuber harus mendapatkan 1.000 pengikut dan 4.000 menit jam tayang selama 12 bulan dari waktu terakhir video diunggah (Google n.d.).

"Seminggu aku upload dua kali. Jadi pas liburan aku nyetok banyak. Nanti tinggal bikin jadwal upload hari Rabu dan Sabtu, fleksibel. Pokoknya seminggu dua kali." -DGS, (20 tahun, Youtuber)

Senada dengan HF, DGS melalui kutipan di atas menyatakan hal yang sama perihal jadwal unggah dan produksi video dilakukannya secara fleksibel. Fleksibilitas waktu membantu DGS untuk mengatur jadwal kuliah, istirahat, dan bekerja. Jam kerja yang cukup fleksibel membantunya untuk mengatur waktu jika suasana hati kurang baik.

Sementara, GHP, perempuan kelahiran Lampung dan lulusan Fakultas Psikologi UGM ini mengaku awal mula menjadi selegram (selebriti instagram) merupakan sebuah "kecelakaan”. Pada mulanya ia tertarik dengan foto produk. Karier menjadi selebgram semakin melejit ketika ia mulai berteman dengan seorang youtuber. Dalam hal penghasilan sebagai selebgram diperolehnya melalui endorsement dan menjadi brand ambassador pada beberapa perusahaan.

"Kalau sebenarnya aku itu tipikal orang yang cepat bosan sih, sebenarnya aku juga sudah agak bosan di sini (di dunia selebgram). Nah, kemarin karena aku bosan dengan konten yang bareng pacar, jadi aku pengin coba cari konten yang psikologi gitu akhirnya." -GHP (23 tahun, Selebgram)

GHP menuturkan bahwa ia mudah bosan dengan suatu hal. Sebagai contoh dalam hal konten ia sempat bosan dengan jenis konten yang dibuatnya. Selama ini konten yang dibuat GHP berkisar pada konten fashion, parodi, dan hiburan. Kini ia mencoba memulai konten edukasi kesehatan mental. Corak kerja yang fleksibel dan selalu mobile juga menjadi keuntungan tersendiri bagi GHP untuk meminimalisasi kebosanan. Kerja dengan corak fleksibel membuatnya tidak hanya terpaku pada satu 
perusahaan, tetapi juga dengan banyak perusahan dengan ritme dan suasana kerja yang berbeda.

Jika menilik dengan apa yang disampaikan Negri dan Hardt (2005), mikro-selebriti termasuk dalam jenis pekerja immaterial. Mikro-selebriti menghasilkan produk imaterial berupa konten seperti video dan gambar (Hardt and Negri 2005). Dalam membuat konten seorang mikro-selebriti dituntut untuk menggabungkan intelektual dan kemampuan komunikasi yang baik. Hal ini menjadi prasyarat utama agar konten yang mereka buat dapat digemari oleh warga net. Fenomena mikro-selebriti juga menunjukkan perubahan pola Fordisme menuju Post- fordisme. Di mana salah satu yang menjadi ciri era post-fordisme ini adalah jam kerja yang lebih fleksibel (Vallas 1999). Perubahan ini menurut Harddan Negri (2005) merupakan bentuk penyesuaian dengan jenis pekerjaan yang lebih mobile dan menyesuaikan pada apa yang dikerjakan.

Young people spend their free time in many different ways. While some spend their free time in informalpursuit or solitary activities, others regulary participate in a range of organized activities. (Furlong dan Carmel 2007: 73)

Kutipan Furlong dan Carmel (2007) di atas menegaskan kaum muda menghabiskan waktu luang mereka dengan berbagai cara baik dalam kegiatan informal maupun kegiatan soliter. Waktu luang ini dipengaruhi oleh budaya lokal maupun nasional. Penulis merefleksikan fleksibilitas jam kerja memberikan ruang bagi kebutuhan pemuda akan leisure time (waktu senggang). Informan menyebutkan bahwa awal mula menjadi mikro-selebriti adalah memanfaatkan waktu senggang, hobi, dan mengasah bakat (soft skill). Dalam konteks ini pilihan generasi muda untuk menjadi mikro-selebriti dipengaruhi oleh perkembangan teknologi internet dan gawai yang masif berkembang pada beberapa dekade terakhir.

Fleksibilitas jam kerja oleh mikro-selebriti justru menjadi sisi lain dari kreativitas
(Hardt \& Negri 2005). Jam kerja yang fleksibel membuat mereka dapat mengatur jam kerja kapan saja. Namun Furlong dan Carmel (2007) menegaskan sisi lain dari fleksilitas jam kerja yakni anak muda harus menegosiasikan terhadap risiko-risiko, sebagaimana dikutip sebagai berikut. As a consequences of these changes, young people today have to negotiate a set of risk which were largely unknown to their parents (Furlong and Cartmel 2007). Anak muda harus menghadapi risiko yang bahkan tidak diketahui oleh orang tua mereka. Dalam sub-bab selanjutnya dipaparkan bentuk negosiasi pemuda lama menghadapi ketidakpastian yang ditimbulkan oleh fleksibilitas pasar kerja.

\section{B. Bernegosiasi dengan Ketidakpastian}

"Orang tua juga menganggap (pekerjaan sebagai
Youtuber) enggak jelas. Akan tetapi, kami ingin
membuktikan bahwa ini jelas. Orang tua cuma men-
ganggap youtube ini cuma sekadar hiburan bukan
pekerjaan". -HF ( 22 tahun, Youtuber)
Dilema menjadi Youtuber dialami oleh seluruh informan, salah satu faktor dilema tersebut berasal dari orang tua. HF menuturkan bahwa orang tuanya hingga saat ini masih menganggap Youtuber bukanlah profesi yang tepat. Hal ini timbul lantaran dunia mikro-selebriti tidak menawarkan proteksi, keamanan, serta jam kerja yang jelas. Perbedaan tersebut menunjukkan perbedaan antara generasi orang tua dan anak. Dalam perspektif generasi menyatakan transisi sosial dan perubahan menciptakan kondisi generasi sosial baru. Kekhawatiran yang dialami oleh orang tua muncul lantaran pasar kerja saat ini semakin mengarah pada prekariat dan sedikit mempertimbangkan hakhak pekerja (Woodman and Wyn 2013).

"Kalau orang tua yang penting kewajiban utama dikerjain, kuliah. Sementara bisa mengerjakan tepat waktu ya enggak papa. Orang tua sih kalau dibilang support dalam hal like dan nonton. Tapi kalau bidang ini ditekuni sebagai profesi, orang tua masih sangsi. Karena ada ketidakpastian itu. Orang tua kan penginnya anaknya sukses, mendapatkan pekerjaan yang pasti.” -AF (22 tahun, Youtuber)

AF menambahkan bahwa fleksibilitas 
pekerjaan sebagai seorang Youtuber membuat orang tua sangsi. Fleksibilitas dalam hal ini dipahami bukan sekadar ketidakpastian jam kerja. Akan tetapi, termasuk pula ketidakpastian pensiun dan jaminan pekerjaan. Dalam menghadapi hal tersebut anak muda terus bernegosiasi dengan membuktikan bahwa apa yang mereka lakukan dapat menjadi sebuah profesi. Di Negara-negara berkembang terutama Indonesia orang tua masih memegang peran penting dalam fase transisi yang dialami oleh pemuda. Dalam hal ini peran orang tua dapat berupa menentukan jenjang pendidikan yang akan ditempuh dan profesi yang akan dipilih oleh pemuda $(\mathrm{Su}-$ topo and Meiji 2014).

Pemuda harus menghadapi tantangan berupa hambatan struktural yang semakin besar seperti sulitnya memperoleh pekerjaan sesuai aspirasi pemuda dan 'ketidakamanan pekerjaan' (job insecurity) (Sutopo and Meiji 2014). Adanya pertentangan dari orang tua dan dari dunia kerja yang semakin berubah membuat pemuda melakukan negosiasi. Di Indonesia pertentangan antar-generasi merupakan suatu hal yang lazim. Nur Kholis Madjid (dalam Naafs and White 2012a) mengatakan kesenjangan antar-generasi terjadi baik dalam keluarga maupun pada tingkatan masyarakat luas. Generasi muda selalu menganggap bahwa generasi sebelumnya kehilangan relevansi dan ketinggalan zaman (Naafs and White 2012a).

Termasuk dalam hal ini pemahaman antar-pasar kerja yang berbeda antar-generasi. Generasi muda menganggap fleksibilitas pasar kerja merupakan tren yang dihadapi dalam era ini. Sementara itu generasi orang tua menganggap bahwa fleksibilitas pasar kerja penuh dengan risiko. Menurut Ulrich Beck, perubahan pasar kerja di era modernitas lanjut ini membuat individu memikul tanggung jawab yang lebih besar (dalam Furlong and Cartmel 2007). Untuk menghadapi risiko itu pemuda melakukan serangkaian strategi dan negosiasi sebagaimana dijelaskan dalam kutipan berikut:

"Awalnya itu mungkin seneng-seneng aja kali ya, mungkin karena aku jadi lebih cepat di-stop secara finansial gitu. Tapi kalau sekarang kadang-kadang itu semakin, "Ayo kamu gimana nih". Sebenarnya orang tua-ku itu lebih ngebebasin, cuma lebih ngasih pandangan aja, "Kamu 5 tahun, 10 tahun ke depan masih bisa di sini?” Ya benar juga, kalau memang mau digelutin terus bikin yang baru tapi aku pun enggak mau selamanya di sini. Kalau misalnya aku enggak mau kerja kantoran at least aku punya tabungan yang bisa buat bikin usaha apa." -GHP (23 tahun, Selebgram)

Sebagaimana yang dijelaskan sebelumnya orang tua memiliki andil dalam keputusan yang diambil oleh anaknya (Sutopo and Meiji 2014). Menjadi seorang miko-selebriti penuh dengan ketidakpastian dan kerentanan. Endorsement yang didapat GHP tidak pasti baik dalam hal kontrak kerja dan penghasilan. GHP berpendapat dengan menjadi pekerja tetap ia dapat mengontrol jumlah penghasilan yang didapatnya setiap bulan.

Dari pernyataan informan di atas $(\mathrm{FH}$, AF, dan GHP) dapat disimpulkan bahwa terjadi perbedaan perspektif generasi yang turut andil dalam menentukan langkah karier seorang mikro-selebriti. Orang tua yang pada umumnya lahir dalam konteks Fordisme, menganggap bekerja secara tetap dan penuh waktu merupakan pekerjaan yang ideal. Perbedaan perspektif ini menimbulkan sebuah negosiasi untuk tetap melanjutkan karier yang tengah mereka jalani. Negosiasi juga dilakukan DGS, penghasilan sebagai Youtuber sebagian Ia sisihkan untuk modal usaha. Kini DGS tengah merintis usaha kedai kopi di Kabupaten Magelang. Ia menuturkan berkat Youtube ia dikenal banyak orang. Hal ini menjadi modal bagi DGS untuk mempromosikan usaha yang tengah ia rintis. Sementara itu GHP terus membutuhkan kepastian untuk status pekerjaannya. Sebagaimana kutipan wawancara berikut ini:

"Jadi enggak ada status yang bisa aku pegang gitu lho, aku butuh status yang kupegang pasti. Kalau kemarin temanku ada yang curhat, dia kan udah lulus, ini menjadi salah satu dilema ku juga, misalnya kayak aku ngantor, aku udah tahu nih salary per bulannya berapa. Terus kadang-kadang aku mikir, sebenarnya aku bisa dapat segitu kurang dari 
sebulan lah, jadi ku ambil enggak ya?" -GHP (23 tahun, Selebgram)

GHP menghadapi situasi dilema antara akan melanjutkan karier sebagai selebgram atau menjadikannya sebagai hobi saja. Dilema itu muncul ketika menghadapi pilihan bekerja di sebuah kantor dengan gaji yang pasti. Hardt dan Negri (2005) menjelaskan fleksibilitas pasar kerja masuk dalam area abu-abu antara bekerja dan tidak bekerja. Dalam bukunya Multitude dengan tegas dituliskan; what is called the flexibility of the labor market means that no job is secure (Hardt and Negri 2005). Ketidakamanan feksibilitas pasar kerja timbul lantaran tidak adanya pembagian kerja yang jelas. Negosiasi merupakan tindakan untuk meminimalisasi risiko yang akan pemuda hadapi dalam menghadapi fleksibilitas pasar kerja (Beck 2006). Bentuk negosiasi yang dilakukan oleh informan dalam hal ini beragam di antaranya dengan berwirausaha maupun melamar pekerjaan di sektor formal.

\section{KESIMPULAN}

Profesi sebagai mikro-selebriti tidak terlepas dari pertentangan-pertentangan baik yang datang dari diri mereka sendiri maupun orang lain. Salah satu yang dibahas dalam penelitian ini pertentangan dan dilema muncul dari orang tua. Dalam perspektif generasi orang tua dan pemuda saat ini lahir dan tumbuh dalam konteks sosial yang berbeda. Dalam hal ini orang tua lahir dalam generasi Fordisme yang masih menganggap pekerjaan sebagai sesuatu yang birokratis dan hierarkis. Sementara itu informan dalam penelitian ini tumbuh dalam konteks sosial Post-fordisme di mana pekerjaan semakian fleksibel. Dengan dihadapkan pada dilema tersebut, mikro-selebriti melakukan negosiasi untuk meminimalisasi terjadinya risiko di antaranya : Pertama, pekerjaan sebagai mikro-selebriti merupakan hobi yang akan terus dijalankan sekaligus dijadikan sebagai pekerjaan utamanya. Kedua, sebagian dari mereka juga meyakini bahwa mereka tetap harus memiliki pekerjaan lain, misalnya mencoba membuka usaha sendiri (berwirausaha) maupun tetap mencoba untuk bekerja di perusahaan atau sektor formal lainnya. 


\section{DAFTAR PUSTAKA}

Anderson, Benedict. 1972. Java in a Time OfRevolution. London: Cornell University Press.

Beck, Ulrich. 2006. Risk Society: Towards a New Modernity. London: Sage Publication.

Cresswell, Jhon W. 2015. Research Design. London: Sage Publication.

Drath, Rainer and Alexander Horch. 2014. "Industrie 4.0: Hit or Hype? [Industry Forum]." IEEE Industrial Electronics Magazine 8(2):56-58.

Fisher, Eran and Christian Fuchs. 2014. Reconsidering Value and Labour in the Digital Age. New York:Palgrave Macmillan.

Flick, Uwe. 2014. The SAGE Handbook of Qualitative Data Analysis. London: Sage Publication.

Florida, Richard. 2012. The Rise of The Creative Class. New York: Basic Book.

Freyssenet, Michel and B. Jetin. 2009. The Second Automobile Revolution. United Kingdom: Palgrave Macmillan.

Furlong, Andy and Fred Cartmel. 2007. Young People and Social Change. New York: Open University Press.

Giddens, Anthony. 2016. "Editorial Foreword." IKAT: The Indonesian Journal of South East Asian Studies 58(02):285-89.

Google. n.d. "YouTube Partner Program Overview, Application Checklist, \&amp; FAQs - AdSense Help.” Retrieved May 30, 2019 (https://support.google.com/adsense/answer/72851?hl=en).

Hardt, Michael and Antonio Negri. 2005. Multitude. London: Penguin Press.

Kasali, Rhenald. 2017. Disruption. Jakarta: Gramedia.

Khamis, Susie, Lawrence Ang, and Raymond Welling. 2017. "Self-Branding, 'Micro-Celebrity' and the Rise of Social Media Influencers." Celebrity Studies 8(2):191-208.
Kozinets, Robert V. 2010. Netnography: Doing Ethnographic Research Online. New Delhi: Sage Publication.

Lindawati, Lisa. 2019. "Kekuatan Cerita Dalam Bisnis Sosial”. Jurnal Studi Pemuda 7(2):100-110.

Marwick, Alice and Danah Boyd. 2011. "To See and Be Seen: Celebrity Practice on Twitter." Convergence 17(2):139-58.

Marwick, Alice E. 2015. "Instafame: Luxury Selfies in the Attention Economy." Public Culture 27(1 75):137-60.

Naafs, Suzanne and Ben White. 2012a. "Generasi Antara: Refleksi Tentang Studi Pemuda Indonesia.” Jurnal Studi Pemuda 1 (2):89106.

Naafs, Suzanne and Ben White. 2012b. "Intermediate Generations: Reflections on Indonesian Youth Studies.” Asia Pacific Journal of Anthropology 13(1):3-20.

Pratitis, Ayu Laras. 2017. "Kerentanan Pekerja Imaterial Dalam Industri Komersialisasi Vlog." MASYARAKAT: Jurnal Sosiologi 22(2): 185-234.

Schawab, Klaus. 2016. The Fourth Industrial Revolution. Geneva: World Economic Forum.

Senft, Theresa M. 2008. Camgirls Book: Celebrity and Community in The Age of Social Network. New York: Peter Lang Publishing.

Simangunsong, Ayu Octasihu F. 2018. "Fenomena Mikroselebriti Di Instagram: Analisis Semiotika Presentasi Diri Karin Novilda.” Pp. 28-53 in Isu-isu Masyarakat Digital Kontemporer. Yogyakarta: Universitas Gadjah Mada.

Standing, Guys. 2011. The Precariat: The New Dangerous Class. New York: Bloomsbury Academic.

Sutopo Oki Rahadianto. 2013. "Hidup Adalah Perjuangan: Strategi Pemuda Yogyakarta Dalam Transisi Dari Dunia Pendidikan Ke Dunia Kerja.” Jurnal Sosiologi Masyarakat 18(2):161-79. 
Sutopo, Oki Rahadianto and Meiji, Nanda Harda Pratama. 2014. “Transisi Pemuda Dalam Masyarakat Risiko: Antara Aspirasi, Hambatan, Dan Ketidakpastian.” Jurnal Universitas Paramadina 11 (3): 1164-1186.

Sutopo, Oki Rahadianto. 2014. "Perspektif Geneerasi Dalam Kajian Kepemudaan." P. 27 in Buku Panduan Studi Kepemudaan. Edited by M. N. Azca, D. S. Widhyharto, and Oki Rahadianto Sutopo. Yogyakarta: Youth Studies Centre FISIPOL UGM. Turkle, Sherry. 2018. Alone Together: Why We Expect More from Technology and Less from Each Other:' Vol. 1. New York: Basic Book.

Ustundag, Alp and Emre Cevikcan. 2018. Industry 4.O: Managing The Digital Transformation. Switzerland: Springer.
Vallas, Steven P. 1999. "Optimization, Protection Rethinking Post-Fordism: The Meaning of Workplace Flexibility." Sociological Theory 172(1): 68-101.

White, Andrew. 2014. Digital Media and Society. Hampsphire: Palgrave Macmillan.

White, Rob and Johanna Wyn. 1998. "Youth Agency and Social Context." Journal of Sociology 34(3):315-26.

Woodman, Dan and Johanna Wyn. 2013. "Youth Policy and Generations: Why Youth Policy Needs to 'Rethink Youth.'" Social Policy and Society 12(2):265-75.

Wyn, Johanna, and Rob White. 1997. Rethinking Youth. Crows Nest: Allen\&Unwin Pty Ltd. 